\title{
REGIONALISMO, LIBERALISMO Y REBELIÓN. COPIAPÓ EN LA GUERRA CIVIL DE 1859
}

\author{
De Revolución a Guerra Civil. \\ Nuevas aproximaciones al levantamiento de Copiapó de 1859
}

Joaquín Fernández Abara, Regionalismo, liberalismo y rebelión. Copiapó en la Guerra Civil de 1859, Santiago, RIL editores, Escuela de Historia, Universidad Finis Terrae, 2016, 317 pp.

Tras las guerras de independencia a inicios del siglo XIX, las emancipadas colonias españolas se vieron enfrentadas al escenario de la incertidumbre política. El común denominador era el deseo de poner fin a tres siglos de dependencia española, tener autonomía política y la tan ansiada libertad de comercio. Estaba medianamente claro qué querían, pero no cómo pretendían lograrlo.

Si bien el ideal era la república, el camino para su consolidación fue complejo y, en algunos casos, tormentoso. Con el principal enemigo al otro lado del Atlántico, aparecieron en la década de 1820 las rencillas entre las colonias y, por cierto, al interior de cada una de ellas. Junto con la lógica disputa por los nuevos límites geopolíticos surgieron las pugnas por el tipo de sistema político que las regirían.

Con un Estado precario e incipiente, la pelea entre unitarios y federales pronto pasó del papel al campo de batalla y es aquí, donde la obra de Fernández nos da un primer atisbo del importante aporte que su trabajo hace a la historiografía nacional chilena.

Por mucho tiempo, y en muchas páginas, se ha acuñado la idea de que en Chile el conflicto entre Santiago y las provincias se solucionó tempranamente a favor de la capital tras las batallas de Lircay y Ochagavía en 1829 y que, con la llegada de José Joaquín Prieto y Diego Portales, el estado unitario gobernó sin mayor resistencia. Es cierto, han sido mencionadas las «revoluciones» de 1851 y 1859 pero sin ahondar mucho en sus causas e implicancias. El autor nos plantea, de partida, que no considera que lo de 1859 haya sido revolución alguna sino derechamente una guerra civil, «por tratarse de una lucha violenta, que enfrentó a bandos definidos, con ejércitos organizados y en operaciones armadas planificadas» (p. 38). El autor despeja esa idea en base a un sólido corpus de fuentes y bibliografía, que avalan sus aseveraciones a lo largo de todo el texto. 
Para llegar a esa afirmación - que el conflicto en el que se vio involucrado Copiapó en 1859 fue una Guerra Civil y no una revolución - el camino que toma Fernández se inicia con una revisión de cómo ha abordado el tema la historiografía nacional desde el texto publicado en 1861 por Domingo Santa María, Diego Barros Arana, Marcial González y José Victorino Lastarria hasta Gabriel Salazar en el año 2007. ${ }^{1}$ Pasando por Encina, Edwards, Grez Toso, Illanes y Ortega, entre muchos otros, el autor da cuenta de que el conflicto constantemente se miró, primero, desde la perspectiva de Santiago, es decir, cómo afectó a Montt y a su gobierno y, segundo, sin ahondar en el origen social, político y económico del problema relegándolo a un mero berrinche de las provincias contra la capital, sin tener mayores consecuencias para el devenir nacional.

A través de su relato, el autor facilita la comprensión, desde la visión de la provincia, en este caso Copiapó, de las relaciones que se tejieron con el poder central y con la élite capitalina, lo cual nos ayuda a comprender de mejor manera la génesis del conflicto.

En el capítulo I, titulado «Los orígenes del descontento regionalista y la formación de un movimiento opositor liberal en Copiapó», Fernández nos ayuda a desatar un nudo fundamental: el que dice relación en cómo, de apoyar al gobierno en 1851 y ser considerado un bastión del peluconismo, Copiapó pasó a levantarse en armas contra ese mismo gobierno en 1859. Las claves están en la Junta de Minería y en la elección parlamentaria y municipal de 1855 , donde salen electos como representantes al parlamento Manuel Antonio Matta y José Victorino Lastarria, dos nombres vinculados irrefutablemente al liberalismo decimonónico.

En el capítulo II, «Crisis Minera y conflicto regionalista» podemos ver la influencia de la crisis económica, el quiebre de los Gallo Goyenechea con la élite de Santiago y la radicalización de la oposición al gobierno. La guerra era inminente.

El capítulo III «Guerra civil y movilización social» nos lleva directo al campo de batalla. Tras la declaración de estado de sitio en Copiapó por parte del poder central y del quiebre definitivo con Santiago, el estallido tuvo lugar el 5 de enero de 1859. Por un lado se vio la capacidad de los que el autor llama los «magnates mineros»-tales como los Gallo, los Matta y los Carvallo- de «movilizar a sus empleados dependientes en el mundo minero como clientelas político y militares, sumada a su poder económico, capaz de financiar las necesidades de un ejército en formación, los pusieron a la cabeza de la organización militar rebelde» (p. 175). Si bien estos magnates dirigían la rebelión, no eran los únicos en levantarse en armas. Artesanos desertores de los cuerpos de policía también se unieron contra el gobierno de Montt. El autor nos muestra los distintos sectores sociales participantes, lo que evidencia que no se trató de un capricho de la élite local sino que, al menos en la frontera minera del Despoblado de Atacama, la excesiva injerencia de Santiago ya no era bien vista por la sociedad copiapina en general.

1. Nos referimos al libro de Diego Barros Arana, Domingo Santa María, José Victorino Lastarria y Marcial González Cuadro bistórico de la administración Montt. Escrito según sus propios documentos, Imprenta del Mercurio de Santos Tornero, Valparaíso, 1861 y al libro de Gabriel Salazar, Mercaderes, empresarios y capitalistas (Chile, siglo XIX), Santiago, Editorial Sudamericana, 2007. 
El cuarto y último capítulo lleva por título «Guerra civil y autonomismo regional». Siguiendo con los pormenores de la guerra, este capítulo nos lleva a los cuarteles rebeldes, donde a los alegatos regionalistas se sumaron los antipresidencialistas. Montt no era el único problema, La Moneda y todo lo que como símbolo representaba, fue puesto en entredicho, del mismo modo que la Constitución de 1833, que ya no gozaba de legitimidad a ojos de los insurgentes, ante lo cual se levantó la exigencia de contar con una nueva Carta Fundamental. Pese a todo lo anterior y a la radicalización del discurso, los copiapinos abogaban por autonomía más no separación.

Los triunfos militares estuvieron del lado de los rebeldes, al menos, hasta abril de 1859. Sin embargo, el dominio marítimo por parte de las fuerzas de gobierno y el quiebre interno de los subversivos a raíz del levantamiento de Pedro León Gallo como caudillo, fueron dos de los factores que terminaron por darle la victoria militar a las tropas proclives a Manuel Montt.

La acuciosa investigación de Joaquín Fernández permite conocer y comprender desde un nuevo ángulo el conflicto de 1859 dejando en claro que la tan mentada estabilidad del Estado unitario no fue tal y que las provincias estuvieron, al menos alertas y en pie de guerra de ser necesario para combatir el poder de Santiago.

El libro nos muestra también la relación existente entre la élite de provincia y la de la capital y lo frágil de su unión cuando las bayonetas se interponen.

La enorme cantidad de fuentes utilizadas por el autor da cuenta del trabajo realizado, que no se sostiene por elucubraciones sino por la evidencia encontrada en documentos oficiales, carta y prensa, entre otras.

Dijimos al comienzo que el trabajo de Joaquín Fernández Abara es un gran aporte a la historiografía nacional, no sólo porque aborda un tema que estuvo en los deslindes de la historiografía chilena por casi 160 años, sino porque, además, abre nuevas perspectivas de análisis respecto a la historia republicana desde la visión de las provincias, que aún se encuentran relegadas por la historiografía, a ser puntos de comparación con Santiago o bien, anecdotarios locales, sin tomar en cuenta que en más de una oportunidad alzaron la voz contra el centralismo durante el siglo XIX. Es hora de que empecemos a develar las huellas que dejaron durante ese proceso y el texto de Fernández es una invitación a ello.

Mariel Rubio Araya Centro de Investigaciones Diego Barros Arana 